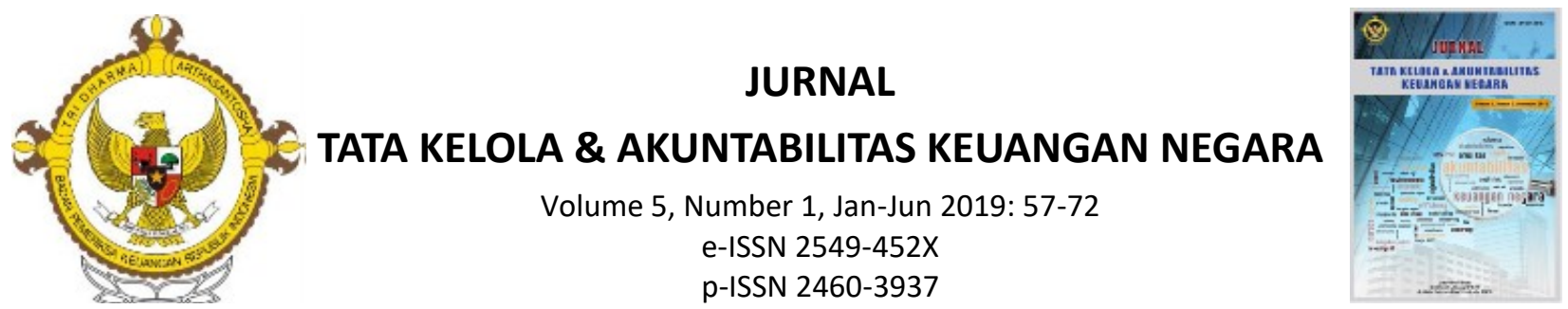

\title{
TRANSPARENCY AND ACCOUNTABILITY AS DETERMINANTS IN THE FINANCIAL MANAGEMENT OF UNIVERSITIES: A STUDY ON STATE UNIVERSITIES IN MALANG CITY
}

\author{
I Wayan Yeremia Natawibawa ${ }^{1}$, I Made Oka Mulya ${ }^{2}$, and Wahyu Hendarto Yoh $^{3}$ \\ Universitas Brawijaya ${ }^{1}$, Universitas Malang ${ }^{2,3}$ \\ Jerry_bali@yahoo.co.id ${ }^{1}$, Okamulyaimade@gmail.com² ${ }^{2}$,wahyohendartoyoh@yahoo.co.id ${ }^{3}$
}

\section{ABSTRACT}

Educational organizations are public sector organizations, making transparency and accountability two important principles that must be reflected in their financial management. This requirement is enshrined in the Law of the Republic of Indonesia Number 12 of 2012 on University. Two factors that can potentially influence transparency and accountability of financial management are the presentation of financial report of the organization in question and accessibility to such statements. This research is intended to analyze the impact of financial report presentation and accessibility to financial reports on transparency and accountability of financial management of a state university in Malang City. Rate of returned and completed questionnaire is $100 \%$, comprising of 252 questionnaires. Data analysis is conducted using multiple linear regression. There are two independent variables used in this research, namely the presentation of financial reports and accessibility to financial reports, and two independent variables, namely transparency and accountability of financial management. The result of this research indicates that the presentation of financial reports and accessibility to financial reports have a positive impact on transparency and accessibility in financial management. This in turn implies that the public would consider that financial management at the state university is accountable if its financial report is prepared in accordance with the applicable standards and easily accessed.

\section{KEYWORDS:}

Presentation of financial report; accessibility; transparency; accountability 


\section{INTRODUCTION}

University is defined by Sudiyono (2004) as an institution providing higher education, research, and renders service to society. Higher education constitutes an activity aimed to create educated individuals by preparing students to become members of society having academic skills and/or professionals with the ability to apply, develop and enrich knowledge, technology, and social arts.

The Education Administration Lecturing Team of Universitas Pendidikan Indonesia (2009) states that educational organizations are public sector organizations. This type of organization are economic entities that have their own unique characteristics and have access to significant or, as some would say substantial resources.

Meanwhile, the objective of non-profit organizations is to provide public services without obtaining financial benefit. Nonprofit organizations are divided into two categories, namely public and private. Public non-private organizations are created by a formal community with the aim of providing service to the general public. Private nonprofit organizations are established by groups of people that focus on a specific service, such as education and healthcare within the community, delivered on a nonprofit basis. Characteristics of a public sector organization is that it is operated without aiming to generate financial benefit, collectively owned by the public, whose ownership of resources is not manifested in negotiable shares, and whose decisions relate to both policies and operational measures based on consensus (Education Administration Lecture Team Universitas Pendidikan Indonesia, 2009).

Educational organizations, including universities, are subject to continuous supervision. Supervision that is effected in the field of education generally refers to efforts to improve the teaching and learning process. The Education Administration Lecture Team of Universitas Pendidikan Indonesia (2009) reported that a number of issues hampering the implementation of supervision include the public's increasing demand for accountability from the educational institutions, which can result in an increasing workload in terms of administrative tasks, particularly during times leading to the conduct of audits. Accountability is also demanded by NGOs and the medias. In addition, issues involving transparency in the management of educational institutions is often the result of conflicts between the policies of educational institutions' management and those of the public, which condition imposes difficulty on the management in undertaking their daily duties (Education Administration Lecture Team Universitas Pendidikan Indonesia, 2009). Natawibawa (2018) states that the budget allocated to the education sector can be viewed as significant, normally constituting $20 \%$ to $30 \%$ of the state budget, increasing the risk of misappropriations in the financial management of education institutions. To reduce the risk of such irregularities, it is important for the management of state universities to ensure disclosure with respect to its financial management within the organizations.

Indonesian Law Number 12 of 2012 on Higher Education stipulates that transparency and accountability are two of a number of important principles that must be observed in managing a university. The enactment of this law marks the moment where universities nationwide must initiated reforms in their management to establish transparent and accountable management of universities in the country. Regardless of the fact that the law clearly provides that the management of universities must meet the principles of transparency and accountabi- 
lity, it still appears that university managers have yet to provide due attention to these principles in the financial management of their organizations. This can be seen from 37 alleged corruption cases found by the Indonesia Corruption Watch (ICW) in state universities, resulting in financial loss by the state amounting to 218,804 Rupiah within a 10 year period, namely from 2006 to August 2016 (JPNN.COM, 2016).

Some of the corruption cases occurring at universities include corruption in the procurement of goods and services, utilization of education grants and funds under the universities' corporate social responsibility program (CSR), internal budges, and scholarship funds for students (JPNN.COM, 2016). According to Siti Juliantari, the enabling factor for prevalent corruption at universities is financial management that lacks accountability and lack of transparency of information with regard to incoming funds, utilization of funds, and the programs that are being implemented (Antikorupsi.org, 2016). Member of the Indonesia Supreme Audit Agency (Badan Pemeriksa Keuangan), Rizal Djalil, has also stated that many universities in Indonesia lack the competence to manage the organization's assets. Additionally, managers of state universities are not transparent (Political News Agency RMOL.co, 2012). This is in line with the views of Masyitoh et al. (2015) in Ikhwan, Subroto and Ghofar (2016) that strong transparency and accountability may have the effect in reducing the potential for corrupt practices. This means that the potential for corruption increases when universities ignore the principles of transparency and accountability.

The issues of transparency and accountability of the management of an organization's resources can be explained by applying the agency theory. The agency theory is an offshoot of the game theory that studies the design of a contract intended to motivate rational agents to act in the interest of its principal when its own interest is in conflict with that of the principal (Scott, 2015). Problems of agency in an organization arises when there is a conflict of interest between the principal as the party owning the funds and the agent as the party in charge of managing the funds aimed to achieve the organization's goals. Funding of an educational institution in Indonesia is comprised of three sources, namely government funding, funds from payment made by students, and funds from other types of financing (Anwar, 2013). Therefore, students have a large interest in seeing transparency and accountability of the management of education institutions as they are an element of society that is directly affected by the education process, which they partake in to become members of society that posses academic skills and ultimately become professionals. This is in line with the views of Sudiyono (2004) that universities must be able to deliver optimal childcentered education service. The term childcentered entails a learning process that is oriented towards the students, whether grade, high school or college students, in order to provide them with the opportunity and facility to develop their knowledge in a self-reliant manner in order to gain a deeper knowledge of their field of study, which in turn would increase their personal quality.

Ball (2009) defines transparency as disclosure to the public, low level of confidentiality among players, dissemination of information for decision making purposes, and a means to demand for accountability. Further, Ball (2009) also proposed an understanding of transparency, namely a request for information, the ability of citizens to acquire information, and the provision and release of actual information by the government as well as non- 
governmental organization (NGOs).

Michener and Bersch (2013) define transparency as recorded information. Michener and Bersch (2013) give an example related to the definition of transparency, namely an occasion where a council or board makes a decision publicly. However, for an outside person such decision cannot be seen as transparent insofar as the process by which it was arrived at is not recorded in a form that can be seen or heard. According to Michener and Bersch (2013), transparency began to be used as a principle in accounting was in the 1980s, when the term started to be widely recognized. Further, Douglas and Meijer (2016) see transparency not only as an tool for external stakeholders to monitor an organization's performance and deter corruption, but also as a tool that can be used by public organizations to actively collaborate with their stakeholders. Organizations' management are expected to continually provide information and educate their stakeholders beyond the extent that they are legally bound to do in disclosing information.

The other principle that must be observed in the financial management of universities is accountability. Abubakar, Dibal, Amade, and Joyce (2017) state that the concept of accountability refer to the way by which resources are utilized in relation to the goals of an organization. According to Abubakar, et al. (2017), accountability is defined as an obligation to maintain a record of the mandate given. Further, Abubakar, et al. (2017) state that the concept of financial accountability of public organization is the extent to which the management of such public organization provides explanation or justification on what it has managed or failed to do for the public or the people within its jurisdiction. A management body that is entrusted with public funds needs to manage such funds for the well-being of the community. As such, financial accountability in this regard is the action of ensure that public funds are used accountably. Financial accountability demands managers of public sector organization ensure that public funds or resources are used wisely and supported by adequate record-keeping methods and presented in the prescribed manner that would allow it to be available to and accessible by the public and delivered in a timely manner to be scrutinized by the public.

Steccolini (2002) defines accountability as the obligation to explain and justify the actions of a person. Steccolini (2002) gives as an example the occasion where an accountant has to furnish information to a person entitled to receive information and such person uses the information to evaluate the accountant. Steccolini (2002) states that accountability constitutes an accountability manifested in the provision of information, and the consequence of that is that evaluation is performed by the receiving party on the information so received. According to Steccolini (2002), accountability is a varied concept. As such, Steccolini (2002) cautions that in interpreting the term accountability, one should determine who is deemed as accountable, to whom, and why such responsibility is called for. An educational organization bears a substantial responsibility to the public as it is funded by multiple sources, one of which are the students, in order for the organization to undertake the role of preparing students to become members of society that posses academic skills and ultimately become professionals in society (Sudiyono, 2004). Therefore, universities are greatly accountable to the students for the management of its resources towards achieving the goals of the organization.

Nurrizkiana, Handayani and Widiastuty (2016) state that one way to enhance 
transparency and accountability of an institution that fall into the category of public sector organization is through the reform of financial report presentation. The financial report of a public sector organization constitute a structured representation of its financial position as a result of the transactions that took place. The better an institution presents its financial reports, the more transparency and accountability can be present in the financial management of the public sector organization. Nurrizkiana, et al. (2017) also state that the inability of a financial report in bringing forth transparency and accountability is not only caused by the unavailability of all the information needed to be contained in the report by the users, but may also be the result of such report not being readily available to and accessible by a potential user.

Several researchers have conducted tests on the effect of financial report presentation and accessibility to financial reports on the transparency and accountability of such reports. Nurrizkiana, et al. (2017) and Hehanussa (2015) have succeeded in proving that the presentation of financial report renders positively influence transparency of financial management. Similarly, the research conducted by Saragih, Ratnawati, and Hanif (2015) also Indria (2018) managed to prove the effect of financial report presentation on the transparency of such report. Further, Nurrizkiana, et al. (2017), Hehanussa (2015), also Wiyana and Syah (2016) have proven that the presentation of financial reports positively impacts accountability of financial reports. Saragih, et al. (2015); Sumiyati, Zulbahridar, and Safitri (2015); also Indria (2018) have also proven that presentation of financial reports affect the accountability of reports. As regards the effect of accessibility to financial reports on the transparency of financial reports, Nurrizkiana, et al. (2017);
Aimbu, Saerang, and Gamaliel (2017); Pasaribu (2011), and Hehanussa (2015) managed to establish that accessibility to financial reports has a positive impact on the transparency of a financial report. The research conducted by Saragih, et al. (2015) as well as Azizah, Junaidi and Setiawan (2018) also managed to prove that accessibility to financial reports positively influences transparency of financial reports. Further, as regards the effect of accessibility to financial reports on the accountability of such reports, Nurrizkiana, et al. (2017), Pasaribu (2011), Hehanussa (2015), also Wiyana and Syah (2016) have found that accessibility to financial reports positively influence the accountability of the reports. Research conducted by Saragih, et al. (2015) and Sumiyati, et al. (2015) also managed to prove that accessibility to financial reports influences the accountability of financial reports.

Researches on the influence test of and accessibility financial reports on their transparency and accountability have yet to yield consistent results. Yuliani (2017) and Azizah, et al. (2018) have found that presentation of a financial report does not render any impact on the transparency of the report. Pasaribu (2011) found that presentation of financial report positively influence transparency of the report. Azizah, et al. (2018) also found that there is no effect of financial report presentation on the accountability of the report, while Pasaribu (2011) concluded that presentation of financial reports rendered a negative impact on the accountability of financial reports. Research conducted by Yuliani (2017) and Indria (2018) found that accessibility to financial reports did not have influence over the transparency of financial reports. In addition, Indria (2018) and Azizah, et al. (2018) have found that accessibility to financial reports did not affect the accountability of the report. 
Bearing in mind the background of the matter as described above, the author intends to retest the effect of financial report presentation and accessibility to financial reports on transparency and accountability of financial reports. The subjects of this research are students of a state university located in Malang City. The research was conducted in Malang City as it has been widely regarded as the city of education since the rule of the Dutch Indies government. This title was given due to the many schools that are located in the city even during the colonial period from 1914 to 1939 , and up to this day there are many universities in

Table 1. Operational definitions of the variables
Malang, drawing students from all over the country to pursue education in the city (Merdeka.com, 2016).

\section{RESEARCH METHOD}

\section{Population and Sampling Method}

The present research or study is a descriptive study. The population of the study are all the students enrolled in state universities in Malang City, comprising of 69,074 students from Brawijaya University, 34,128 students from Universitas Negeri Malang, 17,067 students from Universitas Islam Negeri

\begin{tabular}{|c|c|c|c|}
\hline No. & Variable & Description & Indicator \\
\hline 1. & $\begin{array}{l}\text { presentation } \\
\text { of financial } \\
\text { report }\end{array}$ & $\begin{array}{l}\text { The ease by which to seek } \\
\text { information in an organization's } \\
\text { financial report (Pasaribu, 2011) }\end{array}$ & $\begin{array}{l}\text { 1. Financial report of the university is presented reliably; } \\
\text { 2. Financial report of the university is relevantly presented; } \\
\text { 3. Financial report of the university can be subjected to } \\
\text { comparison; and }\end{array}$ \\
\hline
\end{tabular}

(Nurrizkiana, et al.,2017)

2. accessibility to The ease by which to seek financial report information in an organization's financial report (Pasaribu, 2011).

1. Financial report of the university is published openly through mass media.

2. The university's management facilitates financial report users to obtain information on the university's financial report.

3. Students can access the university's financial reports through the internet (website).

(Pasaribu, 2011)

3. transparency Freedom enjoyed by in financial stakeholders to view the management structure and functions of the organization, the purpose to be achieved through the formulation of a particular policy, and accountability report of the preceding period (Pasaribu, 2011).
1. Availability of an organization system that meets expectations.

2. Accessibility to the university's financial reports that meets expectations.

3. Publication of the university's financial report that meets expectation.

4. Availability of audit reports that meets expectations.

5. Availability of performance information that meets expectations.

(Nurrizkiana, et al.,2017)
4. accountability Accountability relating to the of financial financial integrity of the management organization, disclosure and compliance with the requirements of the law (Pasaribu, 2011).
1. Accountability on the use of public funds by the university.

2. Type and form of investigative financial reports that meet expectations.

3. Timely presentation of financial reports.

4. Audits conducted.

5. Timely response to financial reports of the university. 
Maulana Malik Ibrahim, and 11,410 students from Malang State Polytechnic. The total number of student population enrolled in the universities in Malang City is 131,679 students. The sampling method employed is convenience sampling. The maximum amount of data for analysis using the SPSS version 24 program is 255. As such, determination of the sample size refers to the maximum data that can be input into the SPSS program. Sixty-three students from each university are taken as samples. The variable definitions used in this study and their indicators are presented in Table 1.

Measurement of independent and dependent variables were done using the five-point Likert scale, namely Strongly Agree (SA), Agree (A), Neutral (N), Disagree (D), Strongly Disagree (SD). The research model is as illustrated in Diagram 1.

Diagram 1. Research Model

\begin{tabular}{|c|}
\hline $\begin{array}{c}\text { Presentation of } \\
\text { Financial Report }\end{array}$ \\
\hline $\begin{array}{c}\text { Accessibility of } \\
\text { Financial Report }\end{array}$ \\
$\begin{array}{c}\text { Transparency of } \\
\text { Financial Management }\end{array}$ \\
\hline $\begin{array}{c}\text { Accountability of } \\
\text { Financial Management }\end{array}$ \\
\hline
\end{tabular}

The statistics testing technique used in this research is multiple linear regression, performed with the help of the SPSS Version 24 statistics software. The author will test the validity using the Kaiser-Meyer-Olkin Measure of Sampling Adequacy (KMO MSA) analysis and reliability test using Cronbach Alpha value, followed by regression analysis. After the multiple linear regression is performed, which would result in a regression equation, the next step would be to conduct a classical assumption test. The classical assumption test has the purpose of establishing that the regression resultant equation is not biased, is accurate in its estimate, and consistent. The classical assumption test conducted covers multicollinearity test, heteroscedasticity test, and normality test.

The hypothesis put forward in this study are as follows:

H1 : Presentation of a financial report has a positive influence on the transparency of the financial report.

$\mathrm{H} 2$ : Accessibility to a financial report has a positive influence on the transparency of the financial management.

$\mathrm{H} 3$ : Presentation of financial has a positive influence on the accountability of the financial management.

$\mathrm{H}_{4}$ : Accessibility to a financial report has a positive influence on the accountability of the financial management.

\section{RESULT AND DISCUSSION}

252 questionnaires were distributed to students of Brawijaya University, Malang State University, Maulana Malik Ibrahim Islamic State University, and the Malang State Polytechnic. Questionnaire response rate was $100 \%$. A graphic representation of the respondents are as presented in Table 2.

Results of the validity, reliability and classical assumption tests, which used SPSS Version 24, are as presented in the annexes to this document. Validity and reliability tests show that the overall indicators of this research are valid and reliable. Meanwhile, the classical assumption test indicate an absence of multicollinearity and heteroscedasticity in the regression model and lack of multicollinearity among the independent variables in the regression model. The histogram shows a normal distribution pattern, meaning that the regression model has satisfied the normality assumption.

\section{Hypothesis Testing Result}

The result of the multiple linear regression on the effect of the financial report presenta- 
tion and the accessibility to financial reports against the transparency of financial management is shown in Table 3. Table 3 shows that the two tested relations have a significance value below $5 \%$ and the coefficient has a positive value, which means that $\mathrm{H} 1$ and $\mathrm{H} 2$ are both acceptable. The largest stand- ardized beta coefficient value lies on the variable of accessibility to financial reports. This indicates that such variable on accessibility to financial reports is an independent variable which is more dominant and affects the transparency of financial management, compared to the variable on the financial report

Tabel 2. Respondent Profile

\begin{tabular}{|c|c|c|c|c|}
\hline No. & Item & Remarks & Total & Percentage \\
\hline \multirow{2}{*}{1.} & \multirow{2}{*}{ Sex } & Male & 85 & $33.73 \%$ \\
\hline & & Female & 167 & $66.27 \%$ \\
\hline \multirow{4}{*}{2.} & \multirow{4}{*}{ Age } & $16-20$ years old & 61 & $24.21 \%$ \\
\hline & & $21-25$ years old & 185 & $73.41 \%$ \\
\hline & & $26-30$ years old & 4 & $1.59 \%$ \\
\hline & & $>30$ years old & 2 & $0.79 \%$ \\
\hline \multirow{5}{*}{3.} & \multirow{5}{*}{ Semester } & $1-2$ & 34 & $13.49 \%$ \\
\hline & & $3-4$ & 30 & $11.90 \%$ \\
\hline & & $5-6$ & 43 & $17.06 \%$ \\
\hline & & $7-8$ & 114 & $45.24 \%$ \\
\hline & & $\geq 9$ & 31 & $12.30 \%$ \\
\hline \multirow{6}{*}{4.} & \multirow{6}{*}{ Education level } & D1 & 2 & $0.79 \%$ \\
\hline & & D2 & 5 & $1.98 \%$ \\
\hline & & D3 & 57 & $22.62 \%$ \\
\hline & & D4/Bachelor Degree & 181 & $71.83 \%$ \\
\hline & & S2 (Post-graduate Degree) & 3 & $1.19 \%$ \\
\hline & & S3 (Doctorate Degree) & 2 & $0.79 \%$ \\
\hline
\end{tabular}

Table 3. Result of the Multiple Regression on the Effect of Financial Report Presentation and Accessibility to Financial Report against the Transparency of Financial Management

\begin{tabular}{|c|c|c|c|c|c|}
\hline \multirow{2}{*}{ Model } & \multicolumn{2}{|c|}{ Unstandardized Coefficients } & \multirow{2}{*}{$\begin{array}{c}\text { Standardized } \\
\text { Coefficients } \\
\text { Beta }\end{array}$} & \multirow{2}{*}{$\mathbf{T}$} & \multirow{2}{*}{ Sig. } \\
\hline & $\mathbf{B}$ & Standard Error & & & \\
\hline Constant & 8,244 & 0,811 & & 10,169 & 0,000 \\
\hline $\begin{array}{l}\text { Financial Report } \\
\text { Presentation }\end{array}$ & 0,340 & 0,066 & 0,297 & 5,174 & 0,000 \\
\hline $\begin{array}{l}\text { Accessibility to } \\
\text { Financial Report }\end{array}$ & 0,526 & 0,068 & 0,444 & 7,746 & 0,000 \\
\hline
\end{tabular}


presentation.

The result of the multiple linear regression on the effect of the financial report presentation and the accessibility to financial reports against the accountability of financial management is shown in Table 4. The significance value produced is below $5 \%$ and coefficient has a positive value, by which $\mathrm{H}_{3}$ and $\mathrm{H}_{4}$ is acceptable. The largest standardized beta coefficient lies on the variable of the financial report presentation. This indicates that the variable of financial report presentation is an independent variable which dominantly influence the accountability of the financial management compared to the variable of the accessibility to financial report.

Furthermore, the coefficient of determination in the regression test on the impact of the presentation of financial reports and the accessibility to financial reports against the transparency of financial management is shown in Table 5. R2 is adjusted to 0.427 , meaning that $42.7 \%$ of the variation in transparency of financial management can be explained by variations of the two nonpresentation variable of financial report and accessibility to financial report The rest $(100 \%-42.7 \%=57.3 \%)$ is explained by other causes outside the model. While the independent variables in the presentation of financial report and accessibility to financial report can explain the $34.2 \%$ of the variation in financial management accountability. The rest is explained by other reasons outside the model.

The results of the study show that the presentation of financial reports and accessibility to financial reports have a positive influence on the transparency and accountability of the management of state universities in Malang City. This would mean that principles of the presentation of financial reports are being fulfilled and

Table 4. Result of the Multiple Regression on the Effect of Financial Report Presentation and Accessibility to Financial Report against the Accountability of Financial Management

\begin{tabular}{lccccc}
\hline \multirow{2}{*}{ Model } & \multicolumn{2}{c}{ Unstandardized Coefficients } & $\begin{array}{c}\text { Standardized } \\
\text { Coefficients } \\
\text { Beta }\end{array}$ & T & Sig. \\
\cline { 2 - 5 } Constant & B & Standard Error & & 0.220 & 0.000 \\
\hline $\begin{array}{l}\text { Financial Report } \\
\text { Presentation }\end{array}$ & 0.610 & 0.934 & 0.395 & 6.428 & 0.000 \\
\hline $\begin{array}{l}\text { Accessibility to } \\
\text { Financial Report }\end{array}$ & 0.348 & 0.076 & 0.270 & 4.388 & 0.000 \\
\hline
\end{tabular}

Tabel 5. Determinants Coefficient

\begin{tabular}{lcccc}
\multicolumn{1}{c}{ Relationship } & R & R Square & Adjusted $\boldsymbol{R}$ & Standard Error \\
\hline $\begin{array}{l}\text { Financial Report Presentation and } \\
\text { Accessibility to Financial Report }\end{array}$ & 0.657 & 0.432 & 0.427 & 2.57109 \\
$\begin{array}{l}\text { against the Transparency of Financial } \\
\text { Management }\end{array}$ & & & \\
\hline $\begin{array}{l}\text { Financial Report Presentation and } \\
\text { Accessibility to Financial Report }\end{array}$ & 0.589 & 0.347 & 0.342 & 2.96178 \\
$\begin{array}{l}\text { Against the Accountability in } \\
\text { Financial Management }\end{array}$ & & & & \\
\hline
\end{tabular}


based on the Government Regulation of the Republic of Indonesia Number 71 of 2010, the public would have an easier access to financial reports of state universities in Malang from various available media, and therefore the community (by which in this research refers to the students of the State University) will assume that transparency and accountability of state universities will also be improved. The result of such research that demonstrates the positive influence of the presentation of financial reports as well as accessibility to financial reports for transparency and accountability of financial management is in line with the research result carried out by Nurrizkiana et al. (2017), Aimbu et al. (2017), Saragih, et al. (2015), Sumiyati et al. (2015), Hehanussa (2015), as well as Wiyana and Syah (2016). The result of the research is also in correspondence with the research carried out by Pasaribu (2011) stipulating that presentation of financial report and accessibility to financial management are two important subjects that can influence transparency and accountability of the public sector's financial management.

Indonesian law on Higher Education stipulates that the principle of higher education is when universities have the ability to present relevant information in a precise and accurate manner to stakeholders based on the provisions of the legislation. Transparency and accountability in organisational financial management within the public sector can be achieved if financial reports are presented by including, at least, the posts that covers cash or equivalent to cash, short-term investments, tax receivable and non-tax receivable, inventory, long-term investment, fixed assets, short-term liability, long-term investment, as well as cash equity (Pasaribu 2011).

Pasaribu (2011) states that financial information presented in the balance sheet will increase management accountability and increase transparency in organizational activities. In addition, financial information can be a facility for assessing an entity's financial position by displaying its resources and obligations and providing more extensive information needed in decision making.

Furthermore, Pasaribu (2011) revealed that failure in realizing accountability in organizational financial management was caused not only by the unavailability of relevant information in the organization's annual report, but also because the annual report was not directly available and potential users did not have the convenience to access the report. Pasaribu (2011) discloses that in public sector organizations, community at large needs to be able to know and obtain public sector financial reports easily. The measure of the effectiveness of accountability in public sector organizations is dependent on public convenience in accessing accountability reports and findings to be read and understood by them. Access to obtaining public sector financial reports in the current open democracy can be done through various media, including television stations, radio, magazines, websites or internet networks, newspapers, as well as forums that pay direct attention to the accountability of public sector organizations to the society.

Saragih et al. (2015) states that improved financial report presentation in public sector organizations will certainly have an impact on the clearer financial reporting of the organization's management because all transactions have been carried out based on prevailing regulations and the presentation is complete and accurate hence it impacts the transparency and accountability of the financial reports. Presentations made based on the prevailing regulations and carried out completely and accurately will reduce the occurrence of negligence and fraud in 
financial management in public sector organizations (Sumiyati et al., 2015).

The results of this research show that the presentation of the financial reports of State Universities in Malang City has a positive influence on transparency and accountability in financial management and supported by the condition of State Universities in Malang City which have presented their financial reports based on the principles set forth in the Government Regulations of the Republic of Indonesia Number 71 of 2010 concerning University Financial Reports, namely financial report presentations that are reliable, relevant, comprehensible and comparable. This can be seen from the absence of problems revealed by the media relating to the presentation of financial reports of State Universities in Malang City. This means that State Universities in Malang City have presented their financial reports in accordance with the existing regulations so as the public has the perception that that financial management in State Universities in Malang City has been carried out in a transparent and accountable manner. In accordance with the statement made known by Hehanussa (2015) that it is important for public sector organizations to be able to compile financial reports based on commonly accepted government accounting.

Transparency and accountability in financial management in the public sector are also influenced by the accessibility to financial reports. Aimbu et al. (2017) revealed that the more effective accountability in public sector organizations' financial management is truly dependent on the improved access of the public to comprehensible accountability reports and findings. Nurrizkiana, et al. (2017) who conducted a study of the East Lombok local government revealed that the results of his research were supported by the conditions of the East Lombok local government that published financial reports through various media, such as television stations, radio, magazines, newspapers, and websites. Similar to Nurrizkiana et al. (2017), the results of this study are also supported by the condition of State Universities in Malang that publishes their financial reports through internet media so that the entire community can directly access the financial reports of State Universities in Malang through internet media. Sumiyati et al. (2015) also stated that efforts to produce transparency and accountability in public sector organizations could not be carried out to the maximum if financial report users could not easily access financial reports since providing accessibility of financial reports would result in public trust in the organization's financial management.

\section{CONCLUSION}

This research proves that the two independent variables in this study, namely the presentation of financial reports and the accessibility to financial reports have a positive influence on transparency and accountability in financial management of State Universities in Malang. Thus, to produce transparency and accountability in terms of financial management of State Universities in Malang City, it is deem necessary for the management of State Universities in Malang City to present the financial reports of the organization that refers to the prevailing laws and regulations, specifically financial reports that fulfills the principle of reliability, relevance, comparable and comprehensible. Another aspect that also needs to be taken into account by the management of State Universities in Malang is for the community to easily access the financial reports of the organization through various available media, including through the internet, television stations, magazines, newspapers, radio, etc. 
This study has its limits, as it only uses state universities as the object of research even though there are many private universities. In addition, transparency and accountability of financial management of universities are explained by the two variations of independent variables, namely the presentation of financial reports and the accessibility to financial reports with a low value. This indicates that there are actually many other factors that can affect transparency and accountability in universities' financial management.

The Researcher can furthermore expand the object of research by including private universities as the object of research. Researchers can also add other variables to get a better multiple linear regression model. This is important to get a better understanding of the determinants of transparency and accountability in financial management of universities.

\section{REFERENCES}

Abubakar, A. A., Dibal, N. A., Amade, P., \& Joyce, P. (2017). Effect of internal control activity on financial accountability and transparency in local government areas of Borno State, Nigeria. European Journal of Business and Management, 9(30), 58-65.

Aimbu, L. L., Saerang, D. P. E., \& Gamaliel, H. (2017). Analisis determinan akuntabilitas pengelolaan keuangan daerah (Studi Empiris pada SKPD Pemerintah Kabupaten Kepulauan Talaud). Jurnal Riset Akuntansi dan Auditing "Goodwill”, 8(1). Retrieved from https://ejournal.unsrat.ac.id/ index.php/goodwill/article/ view/15357/14905.

Antikorupsi.org. (2016). Korupsi di perguru- an tinggi. Retrieved from https:// antikorupsi.org/id/news/korupsi-diperguruan-tinggi.

Anwar, M. I. (2013). Administrasi pendidikan dan manajemen biaya pendidikan. Jakarta: PT. Raja Grafindo Persada.

Azizah, N., Junaidi., \& Setiawan, A. R. (2018). Pengaruh penyajian dan aksesibilitas laporan keuangan serta sistem pengendalian internal pemerintah terhadap transparansi dan akuntabilitas pengelolaan keuangan daerah. Jurnal Riset dan Aplikasi: Akuntansi dan Manajemen, 3 (2), 111-120. doi: 10.18382/ jraam.v1i2.18.

Ball, C. (2009). What is transparency?. Public Integrity Journal, 11(4), 293-308.

Douglas, S., \& Meijer, A. (2016). Transparency and public value - analyzing the transparency practices and value creation of public utilities. International Journal of Public Administration, 39(12), 940-951. doi: 10.1080/ 01900692.2015.1064133.

Kantor Berita Politik RMOL.co. (2012). Perguruan tinggi nggak becus kelola aset universitas. Retrieved from https://ekbis.rmol.co/read/2012/o1/ 17/52193/BPK:-Perguruan-TinggiNggak-Becus-Kelola-AsetUniversitas.

Hehanussa, S. J. (2015). Pengaruh penyajian laporan keuangan daerah dan aksesibilitas laporan keuangan daerah terhadap transparansi dan akuntabilitas pengelolaan keuangan daerah Kota Ambon. Conference in Business, Accounting, and Management, 2(1). Retrieved from http:// 
jurnal.unissula.ac.id/index.php/ cbam/article/view/294.

Ikhwan, A. N., Subroto, B., \& Ghofar, A. (2016). The influence of accountability on clean corruption perception in local government. ASSETS: Jurnal Akuntansi dan Pendidikan, 5(2), 129146. doi: 10.25273/jap.v5i2.1194.

Indria, N. A. (2018). Pengaruh penyajian laporan keuangan daerah dan aksesibilitas laporan keuangan terhadap transparansi dan akuntabilitas pengelolaan laporan keuangan pemerintah daerah Kabupaten Tasikmalaya. (Theses). Universitas Islam Negeri Syarif Hidayatullah, Jakarta.

JPNN.COM. (2016). Korupsi di perguruan tinggi negeri sudah ngeri. Retrieved from https://www.jpnn.com/news/ korupsi-di-perguruan-tinggi-negerisudah-ngeri.

Merdeka.com. (2016). Malang sebagai kota pendidikan sejak masa Hindia Belanda. Retrieved from https:// malang.merdeka.com/kabar-malang/ malang-sebagai-kota-pendidikansejak-masa-hindia-belanda160502n.html.

Michener, G., \& Bersch, K. (2013). Identifying transparency. Journal Information Polity, 18(3), 233 - 242.

Natawibawa, I. W. Y. (2018). Determinan minat pengungkapan kecurangan pengelola keuangan pada institusi pendidikan. (Theses). Universitas Brawijaya, Malang.

Nurrizkiana, B., Handayani, L., \& Widiastuty, E. (2017). Determinan transparansi dan akuntabilitas pengel- olaan keuangan daerah dan implikasinya terhadap kepercayaan public-stakeholders. Jurnal Akuntansi dan Investasi, 18(1), 2847 .

Pasaribu, F. J. (2011). Pengaruh penyajian laporan keuangan SKPD dan aksesibilitas laporan keuangan SKPD terhadap transparansi dan akuntabilitas pengelolaan keuangan SKPD. (Theses). Universitas Sumatera Utara, Medan.

Saragih, C. A., Ratnawati, V., \& Hanif, R. A. (2015). Pengaruh penyajian laporan keuangan daerah dan aksesibilitas laporan keuangan daerah terhadap transparansi dan akuntabilitas pengelolaan keuangan daerah Kabupaten Simalungun. Jurnal Online Mahasiswa Fakultas Ekonomi Universitas Riau, 2(2). Retrieved from https://jom.unri.ac.id/index.php/ JOMFEKON/article/view/8831/ 8499 .

Scott, W. R. (2015). Financial Accounting Theory Seventh Edition. United States of America: Pearson Canada Inc.

Steccolini, I. (2002). Local government annual report: an accountability medium?. EIASM Conference on Accounting and Auditing in Sector Public Reforms, Dublin, Ireland.

Sudiyono. (2004). Manajemen pendidikan tinggi. Jakarta: PT. Rineka Cipta.

Sumiyati., Zulbahridar., \& Safitri, D. (2015). Pengaruh penyajian laporan keuangan daerah dan aksesibilitas laporan keuangan daerah terhadap akuntabilitas pengelolaan keuangan daerah (Studi pada SKPD Pemerintah 
Kabupaten Rokan Hilir). Jurnal Online Mahasiswa Fakultas Ekonomi Universitas Riau, 2(2). Retrieved from https://jom.unri.ac.id/ index.php/JOMFEKON/article/ view/9125/o.

Tim Dosen Administrasi Pendidikan Universitas Pendidikan Indonesia. (2008). Manajemen pendidikan. Bandung: Alfabeta.

Wiyana, A., \& Syah, S. (2016). Accessibility determinant and the presentation of regional financial statement towards the accountability of regional financial management. Qualitative and Quantitative Research Review, 1(3).

Yuliani, N. L. (2017). Pengaruh penyajian laporan keuangan, karakteristik kualitatif, aksesibilitas dan pengendalian internal terhadap transparansi laporan keuangan pemerintah daerah. Jurnal Bisnis dan Ekonomi
(JBE), 24(1), $1-14$.

\section{ACKNOWLEDGEMENT}

The Authors would like to thank the Manager of the Governance and State Financial Accountability Journal, the Supreme Audit Agency of the Republic of Indonesia for providing an opportunity for the author to publish this article and may this article be useful for its readers. The authors also would like to show its gratitude to Universitas Brawijaya, Malang State University, Maulana Malik Ibrahim State Islamic University, and Malang State Polytechnic who have tremendously supported the author in obtaining data in order for this research to be completed accordingly. In addition, the authors also wish to thank all those who have provided support for the completion of this research.

\section{APPENDICES}

Appendix 1. Reliability Test Result

\begin{tabular}{ccc}
\hline Cronbach's Alpha & Cronbach's Alpha Based on Standardized Items & N of Items \\
\hline 0,863 & 0,864 & 17 \\
\hline
\end{tabular}

Appendix 2. Validity test Result

\begin{tabular}{|c|c|c|}
\hline \multicolumn{2}{|r|}{ Kaiser-Meyer-Olkin Measure of Sampling Adequacy } & 0,921 \\
\hline \multirow{3}{*}{ Bartlett's Test of Sphericity } & Approx. Chi-Square & 2637,341 \\
\hline & Df & 136 \\
\hline & Sig. & 0,000 \\
\hline
\end{tabular}


TRANSPARENCY AND ACCOUNTABILITY AS DETERMINANTS IN THE FINANCIAL MANAGEMENT OF ... I Wayan Yeremia Natawibawa, I Made Oka Mulya, Wahyu Hendarto Yoh

Appendix 3. Multicolinearity test result with dependent variable of financial management tranparency

\begin{tabular}{|c|c|c|c|c|c|c|c|}
\hline Model & $\begin{array}{r}\text { Uns } \\
\text { Co }\end{array}$ & $\begin{array}{l}\text { dardized } \\
\text { icients } \\
\text { Standard } \\
\text { Error }\end{array}$ & $\begin{array}{c}\text { Standardized } \\
\text { Coefficients } \\
\text { Beta }\end{array}$ & $\mathbf{T}$ & Sig. & $\begin{array}{c}\text { Collinearity } \\
\text { Tolerance }\end{array}$ & $\begin{array}{c}\text { Statistics } \\
\text { VIF }\end{array}$ \\
\hline Constant & 8,244 & 0,811 & & 10,169 & 0,000 & & \\
\hline Presentation of Financial Report & 0,340 & 0,066 & 0,297 & 5,174 & 0,000 & 0,748 & 1,442 \\
\hline Accessibility of Financial Report & 0,526 & 0,068 & 0,444 & 7,746 & 0,000 & 0,693 & 1,442 \\
\hline
\end{tabular}

Appendix 4. Multicolinearity test result with dependent variable of financial management accountability

\begin{tabular}{|c|c|c|c|c|c|c|c|}
\hline Model & $\begin{array}{r}\text { Uns } \\
\text { Co }\end{array}$ & $\begin{array}{l}\text { dardized } \\
\text { icients } \\
\text { Standard } \\
\text { Error }\end{array}$ & $\begin{array}{c}\text { Standardized } \\
\text { Coefficients } \\
\text { Beta }\end{array}$ & $\mathbf{T}$ & Sig. & $\begin{array}{c}\text { Collinearity } \\
\text { Tolerance }\end{array}$ & $\begin{array}{c}\text { Statistics } \\
\text { VIF }\end{array}$ \\
\hline Constant & 8,610 & 0,934 & & 9,220 & 0,000 & & \\
\hline Presentation of Financial Report & 0,486 & 0,076 & 0,395 & 6,428 & 0,000 & 0,693 & 1,442 \\
\hline Accessibility of Financial Report & 0,343 & 0,078 & 0,270 & 4,388 & 0,000 & 0,693 & 1,442 \\
\hline
\end{tabular}

Appendix 5. Heteroscedasticity test result on the effect of presentation of financial report and accessibility of financial report to the financial management transparency and accountability
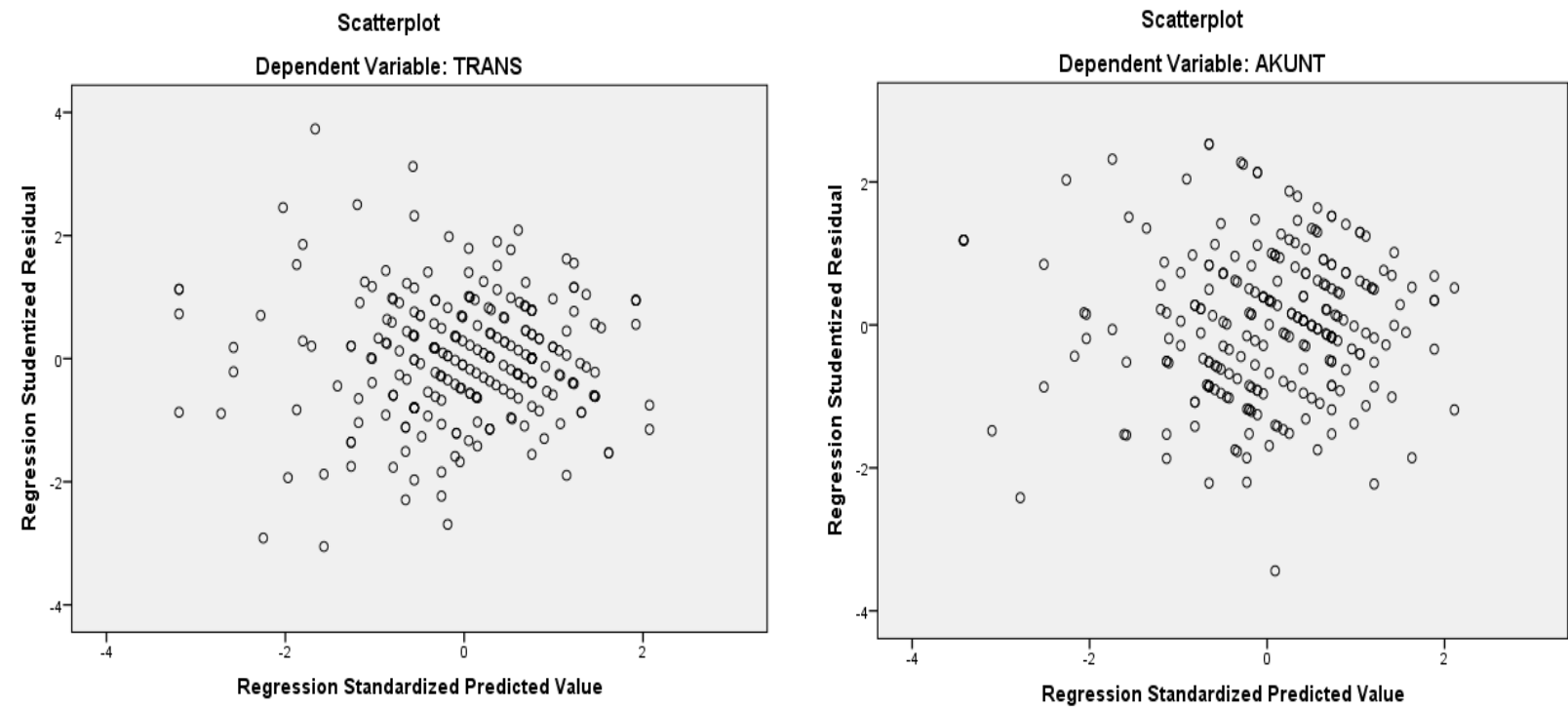
Appendix 6. Normality test result on the effect of presentation of financial report and accessibility of financial report to the financial management transparency and accountability

Histogram

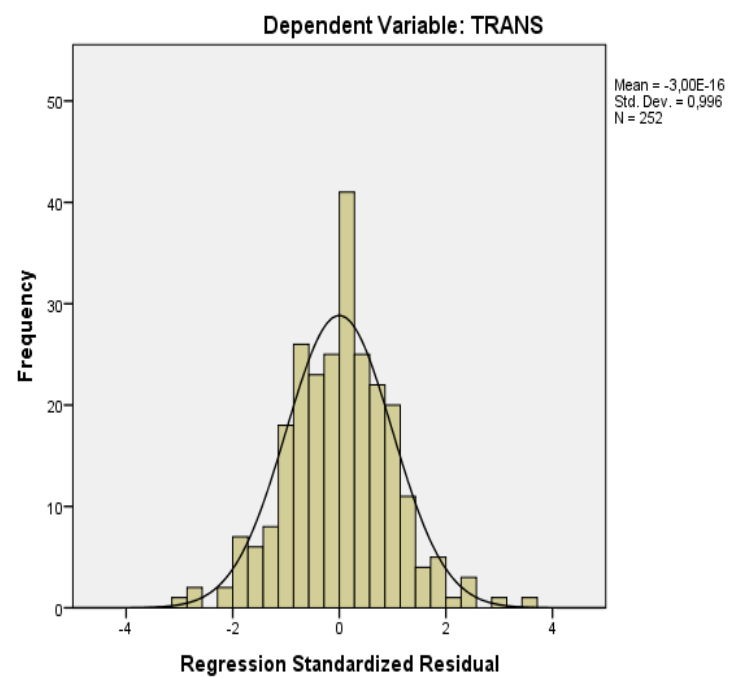

Histogram

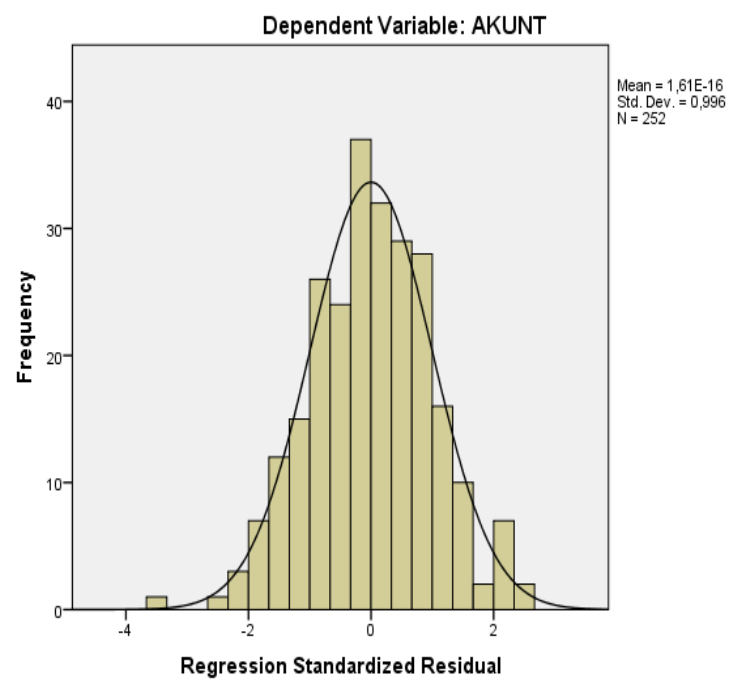

